\title{
The Image of the North in the Yakut Heroic Epic Olonkho
}

\author{
Alina A. Nakhodkina* \\ M.K. Ammosov North-Eastern Federal University \\ 58 Belinsky Str., Yakutsk, 677000, Russia
}

Received 02.03.2018, received in revised form 10.04.2018, accepted 13.04.2018

The article considers the image of the North, its nature, landscape, climatic features, and the antagonist creatures inhabiting it: male and female demons Abaahys and Ajarais, in the material of the Yakut heroic epic Olonkho "Nurgun Botur the Swift" by Platon Alekseevich Oyunsky, a prominent Yakut writer.

Keywords: North, epic, landscape, space orientation, Abaahy, female, danger.

DOI: 10.17516/1997-1370-0250.

Research area: culturology.

\section{Yakut heroic epic Olonkho}

The North is a vast and an endless source of the richest treasury of multiethnic cultural heritage. The Yakut (their selfname is Sakha) people that inhabited the Arctic territory centuries ago brought their fantastic, picturesque oral genre full of poetry and imagination - Olonkho - to the north.

"Olonkho is a general term for the entire Yakut heroic epic that consists of many long legends. ... The epic is believed to be created circa in the $8^{\text {th }}-9^{\text {th }}$ centuries" (Pukhov, 2013: $30-31$ ). Innokentii Pukhov also confirms that the length of Olonkho usually reaches up to 10-15 thousand lines or even more; large pieces of Olonkho reach up to over 20 thousand lines. In the past Yakut Olonkho performers created even larger pieces of Olonkho by blending different plots together, but those pieces were never recorded (Pukhov, 2013: 30).
Epic forms of folklore are created in the early stage of ethnos. Olonkho is an epic of a very ancient origin, originating from the times when the Yakut ancestors lived in their former homeland in the South and closely communicated with the ancestors of the Turk and Mongolian tribes living in the Altay and Sayan regions (Pukhov, 2013: 30). Kurykans, the Yakut people's ancestors, had contact with the ancient Turk people in the $6^{\text {th }}-8^{\text {th }}$ centuries. Considering the fact that Olonkho has the features of connections with ancient Turks, it is quite possible that they originated at the end of the first millennium, approximately in the $8^{\text {th }}$ and $9^{\text {th }}$ centuries. According to the historical stages, the Yakut epic belongs to the later tribal period. A number of features prove that the Yakut epic belongs to the tribal period, namely: Olonkho mythology, reflecting the patriarchal and tribal relations; the remnants of animistic views; the

(C) Siberian Federal University. All rights reserved

* Corresponding author E-mail address: aan-2010@yandex.ru 
plots, featuring battles with fantastic monsters and creatures; the remnants of the general tribal division of hunted goods (remaining in some pieces of Olonkho); and exogamous marriage (Pukhov, 2013: 31). See the example from Nurgun Botur the Swift by Platon Oyunsky:

In ancient times In warring, bloodthirsty times Before the world changed, Beyond the evil horizon Of the awful earlier years ... (Oyunsky, 2014: 4)

The olonkho was considered by Seroshevsky, a Polish scholar exiled to Yakutia, to be one of the most perfect traditional oral forms of literature (Seroshevsky, 1993: 589). The main conflict of the olonkho revolves around a fight between humans - an epic tribe Aiyy, and good and evil spirits Abaahys/Ajarais for peace and balance in the Middle World and is based on the heroic accounts of a warrior, describing his deeds for the sake of the Sakha people (Emelyanov, 1983: 1-10). Sivtsev-Sorun Omollon wrote about the history of olonkho,

"The people called themselves Sakha used to live deep in the South but removed to the Far NorthEast during the great transmigration of peoples. The childhood of the Sakha passed under the hot sun, but their youth and maturity saw the cruel fight with the ice element of the North. Therefore, the bright and magnificent images of the hot South, kept in their memory, mixed with the dark images of the North where the crack of an ice floe turns into the cannon-shot and the fall of a small pebble turns into the avalanche roar. For this reason, the greatness and monumentality of Yakut olonkho and exclusive hyperbolism of its characters, shown, in particular, in the description of brave hunters and courageous warriors, juxtapose with the orientally exuberant, flowery style of lines and colours, sparkled as bright and radiant as fairytale treasure, silk and fur" (Sivtsev-Sorun Omollon, 2011: 12).
In 2005 UNESCO proclaimed Olonkho an intangible masterpiece of human heritage, launching a series of events in the Republic of Sakha such as the foundation of the State Target Program on Reservation, Study and Dissemination of the Yakut Heroic Epic Olonkho, the NEFU Research Institute of Olonkho, the Olonkho Theatre, the Olonkho Land, the Olonkho Portal and many others. 2007 witnessed the start of the large-scale Yakut-English translation project of the Djuluruiar Nyurgun Bootur by Platon Oyunsky in Northeastern Federal University, Yakutsk, which was successfully completed with the English version of Olonkho Nurgun Botur the Swift published in 2013 (2014) by "Renaissance Books" in London.

Djuluruiar Nyurgun Bootur (Nurgun Botur the Swift) is the longest (thirty-six thousand lines) and most famous Sakha epic written by the outstanding Sakha poet, writer, researcher and a founder of the modern Sakha literary language, Platon Alekseevich Oyunsky. He was the first to recreate oral olonkho in a written form. Due to its cultural and literary significance, "Nurgun Botur the Swift" is often referred to as "northern Iliad" and "Sakha Odyssey". The plot of this heroic epic develops around the protagonist, a mighty son of deities, Nurgun Botur who was sent with his beautiful sister Aitalyn Kuo and a younger brother Urung Uolan to the Kyladyky Valley to protect the inhabitants of the Middle World from the constant attacks of the Under World's Ajarais. A demon Abaahy, Timir Jigistei, kidnaps Aitalyn Kuo. Nurgun Botur has to withstand many challenges and fights before rescuing his sister, and connecting his life with a girl-warrior, Kys Nurgun.

\section{Traditional epic space orientation}

The epic space in olonkho consists of three worlds: the Upper World - a land of celestial gods and deities, including demons Abaahys or 
Ajarais responsible for storms, etc.; the Middle World, inhabited by human beings; and the Under World, a location of evil forces only; which are located on the semantic oppositions "north-south" and "west-east". According to Semyonova (Semyonova, 2000: 7), additional distinctive oppositions (stallion/ox, wood/ Araat) to the space lexis mark a specific semantic and symbolic meaning of the parts of the world recorded in culture. The contradiction of "north-south" correlates with the "horse-ox" opposition. The Sakha considered the horse to be a clean animal and connected it with the sky, while the ox, associated with the earth, was opposed to the horse. Cf. Dolgan olongkos that are very close to northern variants of Yakut epic olonkho. They depict a sedentary, not nomadic life. The Aiyy tribe breeds horses and cows that Dolgans never herd, reindeer-herding is never mentioned in Dolgans' olonkho. The Aiyy ride horses called a Turkic term "at"; while the Abaahys ride iron oxen - "ugus" (cf. Turk. О5uз, эгуз, угис - ox; Mong. ухэр cattle) harnessed to iron sledges (Alexeev, Efremov, 2000: 16)

The opposition of "north-south" also functions as the vertical opposition of "downup" realized in the epic olonkho as antagonism of the Upper World and the Under World, i.e. the antagonism of good deities Aiyy and demons Abaahy, which is understood as a contradiction of "good/bad". The contradiction of "east-west" is realized by another space code that could be called topographic, e.g. "wood-sea". This code is connected with the symbolism of parts of the world where "wood" correlates to the east and "sea" - to the west. Due to the traditional solar orientation for the Turkic peoples the east direction - "wood" - is good and the western direction - "sea" - is bad. This opposition is interpreted as a contradiction of the front and rear parts and corresponds to the horizontal space orientation. The west direction is similar to the north direction due to its negative, "bad" symbolism. The Araat Sea and the Kekhtiye Khaan mountain range are located in the west and north-west, and next to them there is a dwelling of the future bride of Nurgun Botur Kys Nurgun, a furious and beautiful warrior-girl with black blood, a lizard in her heart, and frogs in her intestines. When she marries the epic hero, her temper is changed to peaceful, and she moves to the central Kyladyky Valley situated under the Sacred Tree Aar-Luuk Mas. This change is to some extent an obvious improvement.

The epic space is described fragmentarily: landscape is represented in outline. Elements of the landscape such as woods, rivers, mountains, seas, and valleys are also not the object of priority description. The wood is a place of epic hero travelling, while a mountain or seashore is a place of battle.

Chartier wrote, "Imagined spaces, including the North and the Arctic, are constructed by cultural material-language, figures, metaphors, etc. - taken from different sources. They form a rich, complex network of discourses that transmit strong cultural, political, and ideological values. The processing, forming and shaping of these imagined spaces are collective and occur over a long term" (Chartier, 2008: 29).

Traditionally an epic quest starts in the south and leads to the north, imitating the model of the Sakha migration to Siberia. The characters left behind their native land, the blessed sunny world and approached the tundra in their adventures.

His blessed valley Shone like a starlet in the distance... He puffed the fog of the endless tundra, He got to the Under World (Oyunsky, 2014: 272).

The northern territories are described as a dangerous hostile environment; cold badlands with specific fauna: 
Then trotted through the vast tundra. In the enormous bog he came across $A$ nest of the ugliest frogs The size of a pregnant mare; The northern hills He had ridden through Were swarming with monstrous ants The size of a young bull... (Oyunsky, 2014: 162).

and scanty flora:

Where only shrubs grew (Oyunsky, 2014: 349; 377-378; 432),

i.e. tundra and its climate are an objectification of the Under World in the epic.

The boiling fiery fog Was howling And flaring,... The old moon, Rough and dim Reminding us of a skull, Faded, The undercooked-fish-soup-like Foggy sky Became even darker, So the only eyes of The Ajarai people With sores In seven places Were of no use, The muddy sun, Rotten In seven places, Festering In four places, Rusty Like red copper, Was not lighting up The magic surface Of the Under World, So nobody could see anything, It became so dark That even a shout Could not be heard Within a distance of Three days, $A$ dense winter fog Lay around The Ap-Salbaniki abyss, So its passage Could not be seen From a distance Of six days (Oyunsky, 2014: 12).

The epic reproduces real natural northern phenomena such as fog, drifting snow and the polar night season with bright metaphors. The north is represented in the epic only in wintertime; there is no description of any other season.

Traditionally the northern Muus-Kudulu Ocean shore - vast cold wastelands of Onolutta Valley - is used for heroic battles and duels.

The demonic feminine origin of these landscape objects is reflected in the flattering addition 'Khotun-Ebeh' to all place names of such ionic symbolism, either ground (road, valley, or abyss) or water (river, lake, ocean, swamp) that reveal an instinctive fear and respect of the natural forces, e.g. Saidiliki Ebeh Khotun Saidiliki Lake. "Khotun [ho'tun] is a title of an honoured lady; a land lady; a wife. 'Эбэ' (e'beh) - 'grandmother')'.

The eight-channelled Araat Ocean khotun. (Oyunsky, 2014: 50).

Such water objects are considered to be obstacles for the epic heroes; often the heroic battles take place on the seashore or over the sea on a magic rope. As former steppe nomads the Sakha saw a threat and felt a natural distrust of large water basins and call them 'бай5ал' ([bai'gal] - the closest equivalent is 'ocean') which has a negative connotation. Baigals oceans, seas and lakes in the water system of the Sakha epic olonkho are illustrated as 'cold', 'frightening', oxymoronic 'fiery', and 'deadly', even 'evil'. There is a hypothesis that the name of Lake Baikal derives from the Sakha word "bai5al" (Nakhodkina, 2014: 1i).

The spirits of such water basins are supposed to be only evil and male. Hence, the bloody, wormy, fiery seas, rotting swamps and bogs, and all in all a soaking wet environment is typical of the Under World, which in this light is the brightest personification of the hostile feminine symbolism. Thus, we can summarize that there is one more opposition in the epic - "male-female".

The Muus-Kudulu Ocean (literally "Kudulu Icy Ocean") is always cold and dangerous in any season:

Uot Uhutaki oburgu Who was created To be the spirit of Muus Kudulu The bottomless ocean, He slayed the noble warriors Of the Upper world, He slaughtered everybody, He tied them up close to each other With a fiery magic rope; He put them at the dark bottom Of his dungeon... (Oyunsky, 2014: 234).

Uot Uhutaki oburgu, Who lived under the western sky And was known As the vicious spirit Of 
Muus Kudulu the bottomless ocean... (Oyunsky, 2014: 330).

The hydrosphere components as well as mountains belong to the peripheral objects with an analogous negative symbolism; that is why mountains are mostly situated in the west and north, unfavourable directions of the Middle World and in the Under World, and only the tops of some ranges can be seen in the Upper World. Conventionally mountains serve as passages to the Under World.

In $1840^{\text {th }}$ Middendorf recorded the Yakut myth that the Aiyy god created the earth beautiful and smooth but the demon Abaahy trampled down and scratched it. The results of his acts were left in the shape of lakes, rivers and mountains (Ergis, 1974: 110). The very origin of mountains in the epic space made them "dangerous locations where the primeval horror is localized" (Lavrenova, 2010: 107).

Traditionally in a cosmological system a mountain is a vertical locus connecting earth and heaven, top and bottom that define its dual nature: sacral and demonic; the roots of this began in the past.

Gogolev specifies that Orkhon cosmogony, similar to the Sakha, includes three gods Tengri, Umai and Ydyk yer-sub. The Sakha didn't preserve a holistic perception of this Old-Turkic cult: the term "tangara (Old Turk. tengri)" was generalized and now means any god including Christian; the goddess of earth was transformed into the spirit of the Sacred Tree-Aan-Alakhchin Khotun (Gogolev, 1993: 33). S.G. Klyashtorny explains that "within a landscape scheme a yer-sub is perceived as a platitude necessarily attributed by a vertical sacral mountain peak (yduk bash) ..." (Myths of the peoples..., 1982: 537). The Sakha transformed a mountain peak into the Sacred Tree Aar-Luuk Mas which functions as some axis mundi. They also did not preserve the worship of sacral mountain peaks as in their Old Turkic perception (Gogolev, 1993: $33)$; on the contrary they demonized them in the epic.

The highest range Of the great Kenerdekh Kehtiye road, Where cuckoos are sacrificed (Oyunsky, 2014: 354).

In the Sakha epic tradition, a cuckoo was considered "a shaman bird" (Pekarsky, 1958: 1065). The function of "the highest range" as a place of a shamanistic ritual with the sacrifice of cuckoos stipulates the negative semantics of the locus.

The vertical mirror images of them abysses and pits that balance mountains in the epic space - are also demonized in the olonkho, e.g. "etugen" in the epic olonkho - a location of demonic characters - Abaahys, monsters, alien tribes speaking foreign languages, people of other traditions, culture and religion" (Pekarsky, 1958: 236):

On top of a solid etugen, $A$ permanent precipice, On top of a tertugen $-A$ stable, wide abyss... (Oyunsky, 2014: 44).

The greedy trap Of the three laughing abysses Were burning With blue fire, Were flaming With red fire, Surging Up and down... (Oyunsky, 2014: 401).

Eluu Cherkechekh, deadly abyss [e'lju:] [tcherke'tcheh] - a pit, one of the entrances to the Under World. It is among 'three laughing abysses' often mentioned in Olonkho. Eluu - deadly, death; Cherkechekh is a proper name (Nakhodkina, 2014: lii).

Canyons and passes that functionally combine mountains and abysses in the epic space as entrances to the Under World are "equivalent to the zoo- or anthropomorphic monsters" (Semyonova, 2000: 131). 
So, they left behind Their native land Of eight rims, Theypassed the alaas, Theypassed the bush, They left behind The blessed sunny world, Following nine bends on the road, Passed the valley and approached the tundra, Through the macabre mouth Through the gaping gorge Through the crumbling stomach Of the Great Kuktui Khotun, Making the heavens thunder Over the soaking passage, Shooting lightning bolts Down to the death path With rolling stones And trembling trees, Through the Uot Chokhurutta swamp With beetles the size of cattle, Through the breathing Badilitta bog, With toads the size of a cow... (Oyunsky, 2014: 124-125).

Due to the character of the environment's impact on human psyche the environment embodies the main cosmological categories. Tuan points out "landscapes that evoke fear are perceived as manifestation of Chaos" (Cit.: Lavrenova, 2010: 107) This fact is proved by research on mountains in a real landscape: "Mountains as landscape features were, prior to that time, regarded with fear and even disgust as forbidding and dangerous places, until geologists and other scientists began to explore and uncover their secrets leading to an emerging appreciation of their beauty and inspiration" (Paradis, 2008: 60-61).

Thus, such significant landscape elements as water objects, abysses, pits, canyons, and mountains are of a feminine gender that are negative and hostile towards human-beings and gods.

Women in the epic are also represented by other destructive characters: women or girlsAbaahys - demonesses and daughters of ilbis, flying spirits of war, discord and bloodlust. These spirits sow the seeds of strife and hostility and fly over the field of a battle screaming and howling. They live at the top of the spearhead, arrowhead or in the blade of another weapon. They drink blood and when they are hungry, flames of blue or sulphur fire appear on the weapon. Such negative creatures might derive from the patriarchal attitude to women, especially of the enemy tribe. The vitality of these stereotypes is proved by contemporary mass art, a cartoon character of which once said, "I just don't trust anything that bleeds for five days and doesn't die" (Mr. Garrison lesson on women).

\section{The image of enemy and its evolution}

The central theme in Yakut olonkho is the struggle with demons and monsters Abaahys $=$ Ajarais. Abaahys in shaman mythology are evil spirits devouring human souls and bringing diseases. "The description of the obstacles overcome on the way and the very realm of the dead in some variants exactly coincides with the similar moments in shamanistic mysteries. This is not however an episation of these mysteries, but this is just the use of the corresponding shamanic representations less archaic than the epic. In Yakut epics the "impassability" between various worlds is smaller and the "mobility" of the epic hero goes back to the pre-shamanic views of homogeneity of the worlds" (Meletinsky, 2004: 279-280).

Abaahy/Ajarai [a'ba: hi], [a'djarai] are evil and ugly creatures; according to I. Pukhov they are one-armed and one-legged Cyclops made of iron with their faces in the back of their heads (Pukhov, 2013: 33). The only arm of an Abaahy that grows from the centre of his chest and his only leg are forked at the elbow and knee. They represent all the possible sins (wrath, lust, cruelty, infectious diseases, laziness, bestiality, impurity and cannibalism). The Abaahy (evil) characters attack people, rob and destroy their land, and kidnap women. Their world is a vast dark icy land with low red skies, fiery oceans and infinite swamps. The Sakha were blacksmiths and found iron ore in the ground which is why they believe that underground creatures are made of iron. The most traditional transformation of the Abaahy is 
a dragon shape. In Olonkho the part of Abaahy is performed in a dull voice, they have their own special interjections like 'art-tatai', 'buiaka', etc. (Nakhodkina, 2014: li).

Yet epic Abaahys are not just mythological creatures but, first of all, warriors of the alien tribe, enemies. In these very complicated images there are interwoven or still not differentiated the ideas of natural forces and hostile tribes with whom the Yakuts came across and fought with during their advance to the north.

I followed The hot scent, I chased The cold scent, And caught up with my evil enemy, Born in the age of enmity Ehekh Kharbir, Three Shadows, The night stalker, The deceiving twister... (Oyunsky, 2014: 148).

The image of enemy, mostly mythological and fantastic, is syncretic, and it is found in the most ancient Turkic-Mongol epics of Siberia, its plot and style. But to this ancient basis new elements were added - the elements that reflected further historical fates of the epic performers (Meletinsky, 2004: 283). Thus, an Ajarai, the iron man Kytygyras Baranchai the Swiftfoot becomes the friend of the protagonist's younger brother when they both escape from the demon's prison.

And wherever I am I shall come to the rescue. Until then, farewell, my friend!' - Saying this, the man of iron Turned into a celestial raven, Croaked and flew away... (Oyunsky, 2014: 173).

It would never happen to female characters, they do not have close relationships with human women, although they have some human traits. Girl-Abaahys are described as ugly, morbid and aggressive creatures.

There are girls filthy with infectious disease, Unable to give birth to a baby, Looking like the curved skeletons Of sacrificed horses (Oyunsky, 2014: 9).
Upon the daughter of Ajarais... There she stood, Breed of darkness, Spawn of the abyss, Ghastly warrior Of the Under World depths, With a strange lopsided back, Twisting her whirlwind hem, With a trail of burnt turd Following her like a tail; Lifting her shoulders, Sharp like scissors, Reaching out her hideous hands With dirty iron claws, Moving round her crooked knees, Opening slightly her brazen beak, She turned around Her smoke-blackened face (Oyunsky, 2014: 185).

Nevertheless, they are naïve and simpleminded, they are dreaming of the love of an Upper- or Middle World warrior, how they would marry him and have a family in the Middle World.

Blood-thirsty ferocious warrior, Kuo Chamchai Kyskyidaan Kuo, Flirtatious, she curved, Haughtily she stretched Her seven-bylas-long neck. To allure the hero She tried to tuck in Her bulging bottom, Turning and curving This way and that, She tried to straighten Her deformed, lopsided back,

She tried to jut her belly out To resemble a grand wealthy lady. Jauntily she wobbled around; Dangling, clanked her necklace Made of nine shamans' skulls, Clattered her chaplet Made of eight shamaness' jaws, Patted her pendant Made of nine shamans' kneecaps, Rattled her beading Made of eight shamaness' finger bones; Whirled the hem of her motley dress Made of shamaness' skin, Brushed her fur coat Made of carrion's skin; Shreds of rotten skin fell about, Thick clouds of dust rose into the air... (Oyunsky, 2014: 185-186)

However, girl-Abaahys' love of the Upper/ Middle World warriors often becomes the cause of discord and discontent, and provokes wars. Thus, the destructive nature of inhuman female characters in the Olonkho equals that of the North.

The idea of the Under World in the mythology of the Yakuts and Tungus is almost 
merged with the idea of the North, while the Middle World is described as a sunny land. That is why the Abaahys bring not only diseases but cold, winds and bad weather (Meletinsky, 2004: 275). This includes the development of the motif of struggle with Tungus people in the Yakut epic. G.V. Ksenofontov in "Uraanghai-Sakhalar" and I.V. Pukhov in "Yakut heroic epic" discuss this topic. Tungus heroes in Yakut olonkho (Arjaman-Jarjaman, Achyryman-Chachyryman and others, P.A. Oyunsky called his Tungus character - Bokhsogolloy Botur) are depicted as mythological and fantastic but still they are more realistic than Abaahys-demons. These are taiga men dealing with hunting and herding reindeer.

Arjaman-Jarjaman, A famous shaman Riding seven skewbald deer With seven furious idolized betehits (Dancers taking part in the shamanistic ritual, usually three boys and three girls - a footnote-A.N.) (Oyunsky, 2014: 266).

Bokhsogolloi Botur oburgu, Who was born On the top of eight mountains, Who has huge, wooden hunting skis The size of nine uraha, Who had seven mottled deer As fast as a hurricane, The one Who has never been tamed, The one who knows Eighty-eight Malicious tricks, Whose father is the awful ArjamanJarjaman, Who is capable Of ninety-nine cunning transformations... (Oyunsky, 2014: 331).

These characters are contradictive (a Tungus hero acts both as an enemy and as a friend), and this contradiction reflects the historical Yakut-Tungus relationship created before the Yakut joining to Russia. Ethnic specification of the enemy in Olonkho is connected with the process of ethnic consolidation of the Yakuts that is usually depicted in mythological images (Meletinsky, 2004: 284). It is hard to determine the date of origin of the Tungus hero as the main hero's rival in Olonkho. It could be on the Yakut's present native land. (According to historical research, in the early days of their settling in Yakutia there were several conflicts between the Yakuts and indigenous tribes.) In addition, the Yakuts would have been able to meet the Tungus in the Baikal region. However, the heroic epic expresses these ancient relationships of the Yakut and the Tungus in the context of 'heroics' fantastic heroic collisions. In some Olonkho epics, the main hero and the Tungus hero are friends and allies; another epic shows the Tungus hero as protagonist. He struggles with Abaahys and saves people. It is quite possible that the character of the Tungus as the main epic hero is a result of late folk art, which suggests a higher plane of intelligence.

A careful study of Olonkho reveals such assimilations of Yakut epic tradition in the folklore of the indigenous peoples of the North Dolgans, for example: in the form of narration, the performing style and the contents, some motifs or plots, e.g. a motif of a protagonist sister's kidnapping by a Tungus hero riding a fast-moving reindeer sled.

Beautiful Aitalyn Кио ... found herself lying Across the lap Of that old Tungus, Who was heading due south, Raising clouds of snow, Like a whirlwind, Leaving a fire trace Half of a birch-bark bucket wide, Driving his seven-speckled deer Like a ghost not touching the earth... (Oyunsky, 2014: 160).

In the majority of Olonkho epics, the Tungus acts as a hero's rival in marriage and loses out in the struggle for a bride. The Tungus hero struggles only for a bride, there are no other conflicts involving him. He is depicted as a smart, cunning and artful hero. In the relationship between the main hero and the Tungus hero the pursuit for a peaceful relationship between the Yakuts and the Tungus (trading, common festivities) is clearly evident. 
"In the historical time" since the $17^{\text {th }}$ century the Yakuts did not have a holistic mythological system but the olonkho epic preserves its ancient narration. In the epoch of heroic epic genesis (by the southern ancestors of Sakha) there might be a generalization of main mythological plots of cosmogonic character. Later in the Middle Lena during the period of the enthnos' formation those mythological images generated in South Siberia and central Asia begin to fade and are forgotten (Sivtsev-Sorun Omollon, 2011: 6).

\section{Conclusion}

Thus, the Yakut heroic epic olonkho "Nurgun Botur the Swift" by Platon Oyunsky shows the North as a hostile land full of danger to newcomers who migrated there from the southern territories. The hostility of the North in the epic space is proven with its traditional negative space orientation semantics, the landscape inhabited by evil feminine spirits. The epic quest starts in the south and leads to the north, imitating the model of the Sakha migration from the south to the north. The epic hero faces the obstacles on his way like his ancestors while migrating. The description of the terrible Under World environment reproduces typical natural phenomena of the Arctic region such as eternal cold, ice, fog, darkness, polar night season, the lack of fresh air, the absence of vegetation but at the same time presence of ugly insects and reptiles. Tundra and permafrost become an objectification of the Under World the land of demons Abaahys - Ajarais. Blue and green fire of stinky swamps or oceans burning with volcanic fire in the Under World indicate that the Sakha had an idea of mineral reserves of natural gas, oil, and coal in the North.

The antagonist inhuman feminine images embody natural forces and probably the females of hostile tribes - warrior-ladies; this explains their supernatural power, zoo- and anthropomorfic monstrosity, animosity, warlike attitude, repulsive appearance, bad temper, and infectious diseases. The male antagonists also represent the mythologized images of enemies that, however, evolve in the course of the narrattive.

A careful study of the Sakha epic olonkho reveals certain similarities with folklore of the indigenous peoples of the North: in the form, style and content, some motifs or plots, e.g. the scene of the protagonist sister's kidnapping by a Tungus hero riding a fast-moving reindeer sled.

With a lapse of time the image of enemymonsters is displaced by the image of the Tungus inhabited northern territories where the Sakha tribes migrated. The new antagonists are still hyperbolized but they gradually lose their mythologization and become closer to real human beings. Moreover the negative impact of the Tungus is reduced to an unsuccessful attempt to capture a woman (sister or bride of the protagonist), often this hero performs a comic role in the epic and ceases to frighten.

However, in general, the image of the North in the Yakut heroic epic olonkho still acts as a hostile force to man.

\section{References}

Alekseev, N., Efremov, P. (2000). Folklor Dolgan [Folklore of the Dolgans]. Novosibirsk: Russian Academy of Sciences Siberian Division Institute of Archaelogy and Ethnography Publishing House.

Chartier, D. (2008). The Gender of Ice and Snow. In Journal of Northern Studies, 2, 29-49.

Emelyanov, N. (1983). Syuzhety rannikh tipov yakutskikh oloykho [Plots of early Yakut olojkho]. Moscow: Nauka.

Ergis, G.U. (1974). Ocherki po yakutskomu folkloru [Essays on Yakut folklore]. Moscow: Nauka.

$$
-587-
$$


Gogolev, A. (1993). Yakuti (problemi etnogeneza i formirovanie kul'turi) [The Yakuts (issues of ethnogenesis and formation of culture]. Yakutsk: Yakutsk State University Press.

Ksenofontov, G. (1937). Uraankhai-Sakhalar. Ocherki po dervnei istorii yakutov [UraanghaiSakhalar. Essays on the ancient history of the Yakuts]. Irkutsk.

Lavrenova, O.A. (2010). Space and senses: Semantics of cultural landscape. Moscow: Institute of the Heritage.

Meletinsky, E. (2004). Proishozhdenie geroicheskogo eposa. Rannie formy $i$ arhaicheskie pamyatniki [The Genesis of the heroic epic: Early forms and archaic monuments]. 2nd ed. Moscow: Vostochnaya literatura.

Mr. Garrison lesson on women. In Youtube. Available at:https://www.youtube.com/ watch? $\mathrm{v}=\mathrm{ZDUq} 9 \mathrm{BBr} 3 \mathrm{bA}$

Myths of the peoples of the world (1982). Encyclopedia. Vol. 2. Moscow.

Nakhodkina, A. (2014). Select Glossary and Commentaries in Oyunsky, P.A. Nurgun Botur the Swift. English translation supervised by Alina Nakhodkina. London: Renaissance Books.

Oyunsky, P. (2014). Nurgun Botur the Swift. English translation supervised by Alina Nakhodkina. London: Renaissance Books.

Paradis, R. (2008). A comparative landscape study of the mountains of northern New England and the Highlands of Scotland. Ann Arbor, USA.

Pekarsky, E. (1958). Slovar' yakutskogo yazika [The Dictionary of the Yakut Language]. Yakutsk.

Pukhov, I. (2013). Olonkho - drevnii epos yakutov [Olonkho the ancient Yakut epic]. Yakutsk: Saidam.

Semyonova, L. (2000). Semantika prostranstva i ee rol'v syuzhetoobrazovanii (na materiale yakutskogo eposa olonkho) [Semantics of the epic space and its role in plot (on the material of the Yakut epic olonkho]: a dissertation submitted for a Candidate of Culturology at the Russian State Humanitarian University, Moscow.

Seroshevsky, V. (1993 [1896]). Yakuty: Opyt etnograficheskogo issledovaniya [The Yakuts: Results of an ethnographical study]. Moscow: Rossiyskaya politicheskaya entsiklopediya.

Sivtsev-Sorun Omollon, D.K. (2011). O yakutskom epose olonkho [About Yakut epos olonkho]. Yakutsk: North-Eastern Federal University Press.

Tuan. (1979). In Lavrenova, O. (2010). Space and senses: Semantics of cultural landscape. Moscow: Institute of the Heritage. 


\section{Образ Севера в якутском героическом эпосе}

\section{Олонхо}

А.А. Находкина

Северо-Восточный федеральный университет

им. М.К. Аммосова

Россия, 677000, Якутск, ул. Белинского, 58

В статье рассматривается образ Севера, его природа, ландшафт, климатические особенности, населяюшие его существа-антагонисты: мужские и женские образы демонов абаасы и аджараев, на материале якутского героического эпоса олонхо «Нюргун Боотур Стремительный» Платона Алексеевича Ойунского, выдаюшегося якутского писателя.

Ключевые слова: Север, эпос, ландшафт, пространственная ориентация, абаасы, женские образы, опасность.

Научная специиальность: 24.00.00 - культурология. 